\title{
Free Radical Scavenging and Cytotoxic Activities of Substituted Pyrimidines
}

\author{
Qurat-ul-Ain ${ }^{1,2 *}$ \\ ${ }^{1}$ Dr. Panjwani Center for Molecular Medicine and Drug Research, International Center for Chemical and Biological Sciences, University of Karachi, \\ Karachi-75270, Pakistan
}

${ }^{2}$ Department of Pharmaceutical Chemistry, Faculty of Pharmacy, Hamdard University, Karachi Pakistan

Submission: May 21,2020; Published: June 12, 2020

*Corresponding author: Qurat-ul-Ain, Assistant Professor of Pharmaceutical Chemistry, Faculty of Pharmacy, Hamdard University, Karachi - 74600, Pakistan

\begin{abstract}
A library of substituted pyrimidines was synthesized and evaluated for free radical scavenging, and in vitro cytotoxic activity in 3T3 cells. All compounds showed good free radical scavenging activity with IC50 values in the range of $42.9 \pm 0.31$ to $438.3 \pm 3.3 \mu \mathrm{M}$ as compared to the standard butylated hydroxytoluene having IC50 value of $128.83 \pm 2.1 \mu \mathrm{M}$. The structure activity-relationship was also established. Selected analogues $1,2,3,5,6,7,8,9,10,12,13,15,19,20,21,24,25,26$ and 28 were tested for cytotoxicity in mouse fibroblast 3T3 cell line using MTT assay, and most of the analogues showed cytotoxicity. This study has identified a number of cytotoxic novel substituted pyrimidines having free radical scavenging activities that can be used as inhibitory compounds for those cancer cells whose growth is mediated by reactive oxygen species.
\end{abstract}

Keywords: Pyrimidine nucleotide, Synthesis, Free radical scavenging, SAR, Cytotoxicity

Abbreviations: MTT: 3-(4,5-dimethylthiazol-2-yl)-2,5-diphenyl tetrazolium bromide

\section{Introduction}

Scavenging of free radicals by antioxidant compounds is an important biological function that may maintain in the body a low oxidative damage [1-3]. Antioxidant compounds of different synthetic, and natural sources can scavenge these free radicals with the formation of less reactive species, and thus diminish the radical induced oxidative damage that is possibly associated with many diseases, including cancers [2-5]. Numerous classes of synthetic compounds have been screened to reveal their free radical scavenging ability, including synthetically obtained deoxyribonucleic acids (DNA) and nucleotide analogues like pyrimidine derivatives $[6,7]$.

These pyrimidines, present in numerous pharmaceutically important compounds, have been known to prevent cancer cell proliferation. Substituted pyrimidines primarily display their anticancer activity through intercalating with DNA nucleotide bases. However, they may prevent ROS induced DNA mutations in a way similar to other anticancer and antiviral molecules [811]. In recent years, anticancer drugs already being used in medical practice or being tested in clinical studies have been often based on pyrimidine skeleton, and new pyrimidine derivatives continue to show promising activities [12-15]. However, synthesis of antioxidant molecules can be a new approach to prevent proliferation of tumors whose growth is mediated by oxygen species [16].

Besides their anti-tumor action, pyrimidine derivatives have also been found to possess additional biological activities including antibacterial, anti-folate, antibiotic, anti-HIV, anti-fungal, antimycobacterial, anti-leishmanial were also found to inhibit tumor necrotic factor alpha (TNF- $\alpha$ ) production and as potent inhibitors of urease enzyme [17-21]. Herein, we report the free radical scavenging activities of a new library of pyrimidine derivatives to evaluate their potential against free radical sustained cancer cell proliferation. IN the past, a number of pyrimidines were also found to inhibit enzymes such as tyrosine kinases, urease, $\beta$-glucuronidase, and cholinesterase [22-25]. Furthermore, many pyrimidine analogues were found to exhibit inhibitory or modulatory activities in a number of biological situations [26,27]. Therefore, we screen these synthetic pyrimidine derivatives for their in vitro free radical scavenging activity as well as to establish their cytotoxicity in a 3T3 mouse fibroblast cell line (Figure 1). 


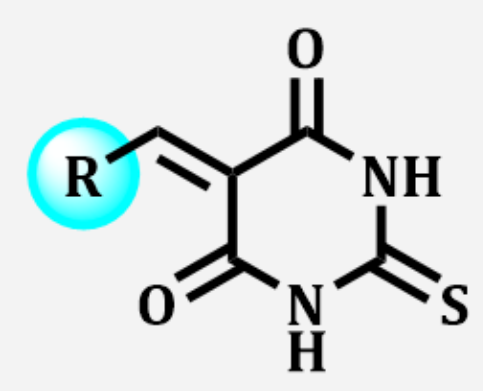

Figure 1: Basic Skeleton of Pyrimidines.

\section{Material and Methods}

All substituted pyrimidines were obtained from the in-house Molecular Bank facility of the Dr. Panjwani Center for Molecular Medicine and Drug Research, International Center for Chemical and Biological Sciences, University of Karachi, Pakistan. DPPH was purchased from Sigma Aldrich (Germany). Ethanol and dimethyl sulfoxide (DMSO) (reagent grade) were purchased from Sigma Aldrich (USA). Standard compounds, i.e., butylated hydroxytoluene was purchased from Sigma Aldrich (Germany).

\section{DPPH Radical Scavenging Assay}

The Kumari Madhu method of DPPH (2,2-diphenyl-1-picrylhydrazyl) assay [28] was used to measure the free radical scavenging activity with small variations. This assay is based on the reduction of DPPH radical (violet colour) by free radical scavenger with a change of colour to pale yellow. The intensity of colour conversion is directly related to the potency of free radical scavenging compounds, and to the extent of reduction in absorbance. In the visible region, absorbance reduction can be measure at $517 \mathrm{~nm}$. Compounds solutions of $(0.5 \mathrm{mM})$ in DMSO were prepared. Two-fold dilution method was used to dilute compounds solutions to different concentrations. $5 \mu \mathrm{l}$ sample of each concentration was transferred to 96 wells plate in triplet, at $517 \mathrm{~nm}$ pre read was recorded. $95 \mu \mathrm{l}$ of $0.3 \mathrm{mM}$ freshly prepared ethanolic solution of DPPH was added in each of the 96 wells. A final absorbance reading was taken at $517 \mathrm{~nm}$. DMSO was used as negative control and butylated hydroxytoluene was used as the positive control. The radical scavenging activities were calculated by the following equation:

\% Radical scavenging activity of DPPH

$=[\mathrm{A} 0-\mathrm{A} 1 / \mathrm{A} 0] \times 100$

Where:

A0: The absorbance of all reagents without the tested compounds.

A1: The absorbance in the presence of test compounds.

\section{MTT Assay}

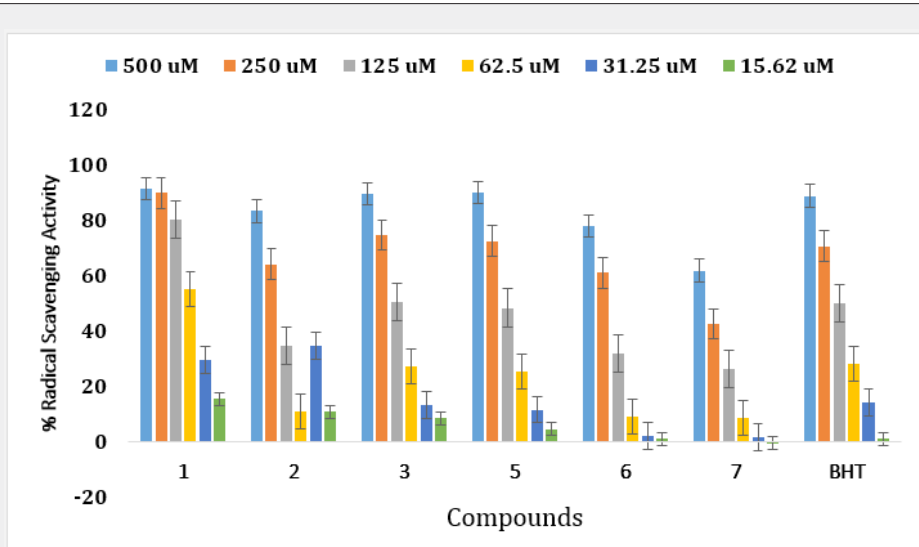

Figure 2: Concentrations dependent changes in free radical scavenging activities of pyrimidine derivatives [1-7]. 
The pyrimidine derivatives were tested by the method previously described by Dimas et al. to establish their cytotoxicities in a normal cell line [29]. In 96-well plate, mouse fibroblast 3T3- cells $\left(2 \times 10^{5}\right.$ cells/ $\left.\mathrm{mL}\right)$ were grown over night in DMEM medium along with 10\% FBS, pen/ strep (100 units/ $\mathrm{mL}$ ), supplemented with $5 \% \mathrm{CO}_{2}$ at $37^{\circ} \mathrm{C}$. After $24 \mathrm{~h}$, the old media was discarded, cells were treated with different concentrations of the tested compound, and further incubated for $24 \mathrm{~h}$. After $24 \mathrm{~h}$,

\section{Results and Discussion}

\section{Free Radical Scavenging Activity}

cells were washed, and the plate was again incubated with MTT solution for $4 \mathrm{~h}$ after which dimethyl sulfoxide $100 \mathrm{uL}$ added for 15 min to dissolved formazan crystals at room temperature. Finally, a micro plate reader (SpectraMax Plus-384) was used to record the absorbance at $540 \mathrm{~nm}$. The $\mathrm{IC}_{50}$ was calculated and defined as the drug concentration $(\mu \mathrm{M})$ causing cytotoxicity in $50 \%$. Cells (Figure 2).

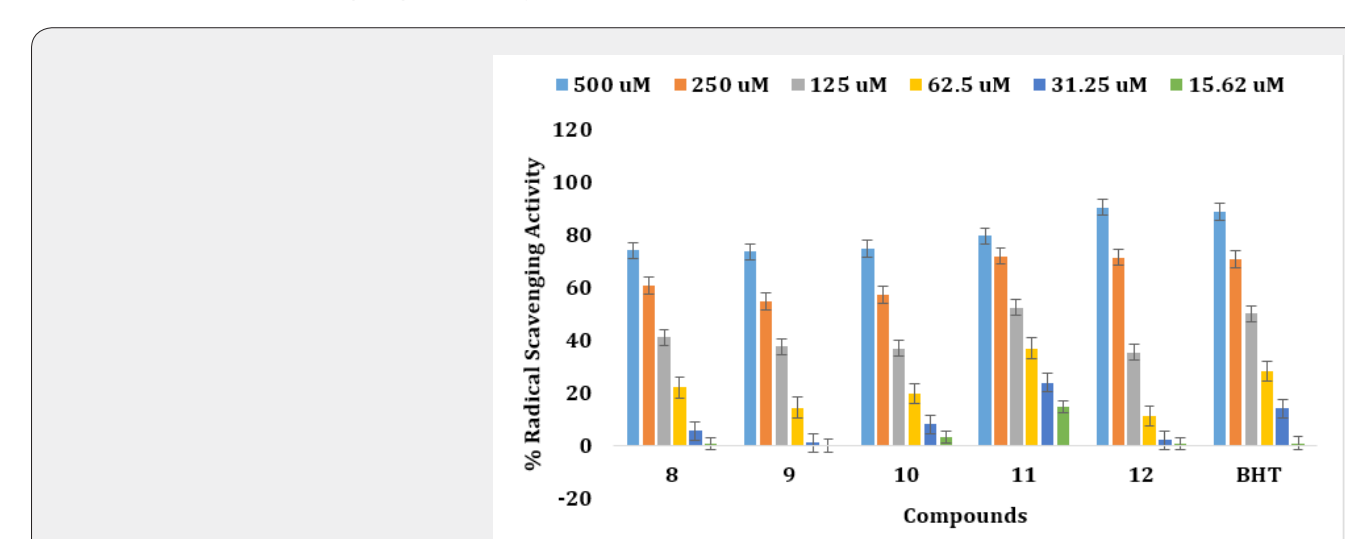

Figure 3: Concentrations dependent changes in free radical scavenging activities of pyrimidine derivatives [8-12].

The synthetic pyrimidine derivatives 1-28 were tested for their free radical scavenging, and cell cytotoxic potential. All compounds showed various degrees of radical scavenging activity in DPPH radical scavenging assay, and their $\mathrm{IC}_{50}$ values ranged between $42.9 \pm 0.31$ to $438.3 \pm 3.3 \mu \mathrm{M}$. Derivatives $\mathbf{1}, \mathbf{3}, \mathbf{1 1}, \mathbf{1 3}$, 18, 26, and 28 with $I_{50}$ values of $55.6 \pm 2.1,122.4 \pm 1.9,107.65$ $\pm 1.3,108.4 \pm 2.8,113.4 \pm 1.3,42.9 \pm 0.31$, and $65.7 \pm 1.80 \mu \mathrm{M}$, respectively, showed free radical inhibitory activity that is many folds better than the standard butylated hydroxytoluene with $\mathrm{IC}_{50}$ value of $128.83 \pm 2.1 \mu \mathrm{M}$, as depicted in Figures 2-5, and TableCompounds 2, 5, 8, 12, 19, and 27 showed good to moderate activities (Figures 2-5 \& Table 1). The remaining derivatives, including $6,7,9,10,15,21,22,23$, and 24 showed weak inhibitory activities (Figures 2-5 \& Table 1). Derivatives 4, 14, 16, 17, 20, 25 were declared as inactive derivatives of this series.

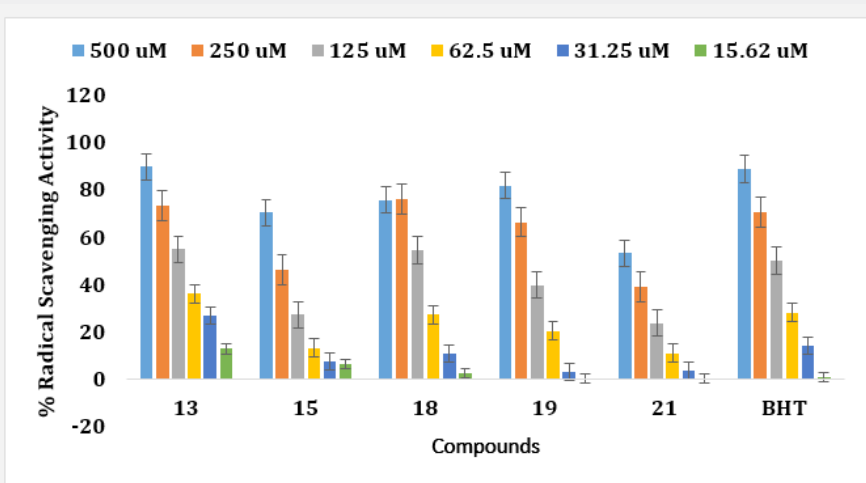

Figure 4: Concentrations dependent changes in free radical scavenging activities of pyrimidine derivatives [13-21].

\section{Structure- Activity Relationship}

A structure-activity relationship established for all compounds that confirmed substitution of various functionalities at the aromatic ring confers free radical scavenging activity to each particular pyrimidine analogue. Analogue 26, a 3,4-dihydroxybenzylidene was found to be the most active pyrimidine among the series, with an $\mathrm{IC}_{50}$ value of $42.9 \pm 0.31 \mu \mathrm{M}$, 
corresponding to $84.07 \%$ radical scavenging activity that is as good as $85.87 \%$ radical scavenging activity of the standard drug (Tables 1 \& 2). The high activity shown by analogue 26 is due to the positional change of dihydroxyl groups present an aromatic moiety (Table 1). Literature reports have also shown that the phenolic hydroxyl group is responsible for the antioxidant function [21,24] (Figure 3).

Table 1: Free radical scavenging activity of compounds [1-28].

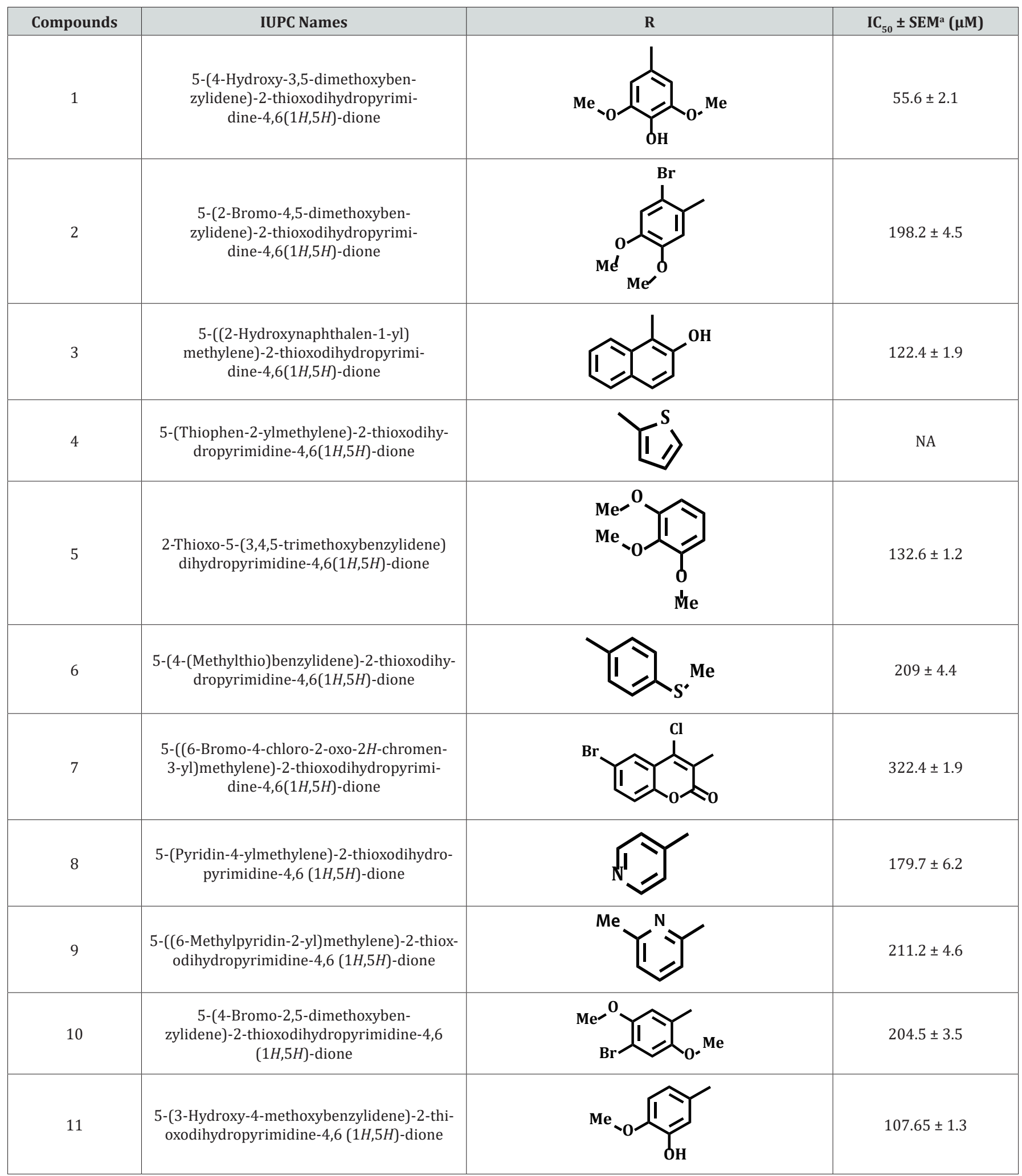




\begin{tabular}{|c|c|c|}
\hline 12 & $\begin{array}{l}\text { 5-(3,4-Dimethoxybenzylidene)-2-thioxodihy- } \\
\text { dropyrimidine-4,6 }(1 H, 5 H) \text {-dione }\end{array}$ & $170.4 \pm 2.5$ \\
\hline 13 & $\begin{array}{l}\text { 5-(4-Hydroxy-3-iodo-5-methoxyben- } \\
\text { zylidene)-2-thioxodihydropyrimidine-4,6 } \\
(1 H, 5 H) \text {-dione }\end{array}$ & $108.4 \pm 2.8$ \\
\hline 14 & $\begin{array}{l}\text { 5-(Anthracen-9-ylmethylene)-2-thioxodihy- } \\
\text { dropyrimidine- } 4,6(1 H, 5 H) \text {-dione }\end{array}$ & NA \\
\hline 15 & $\begin{array}{l}\text { 5-(2-Hydroxy-4-methoxybenzylidene)-2-thi- } \\
\text { oxodihydropyrimidine-4,6 }(1 H, 5 H) \text {-dione }\end{array}$ & $284.2 \pm 5.9$ \\
\hline 16 & $\begin{array}{l}\text { 5-(2,4-Di-tert-butyl-3-chloroben- } \\
\text { zylidene)-2-thioxodihydropyrimidine-4,6 } \\
(1 H, 5 H) \text {-dione }\end{array}$ & NA \\
\hline 17 & $\begin{array}{l}\text { 5-(2-Aminobenzylidene)-2-thioxodihydropy- } \\
\text { rimidine-4,6 }(1 H, 5 H) \text {-dione }\end{array}$ & NA \\
\hline 18 & $\begin{array}{c}\text { 5,5'-(1,4-Phenylenebis(methanylylidene)) } \\
\text { bis(2-thioxodihydropyrimidine-4,6 } \\
(1 H, 5 H) \text {-dione) }\end{array}$ & $113.45 \pm 1.130$ \\
\hline 19 & $\begin{array}{l}\text { 5-(3,5-Dibromo-4-hydroxyben- } \\
\text { zylidene)-2-thioxodihydropyrimidine-4,6 } \\
(1 H, 5 H) \text {-dione }\end{array}$ & $170.87 \pm 1.34$ \\
\hline 20 & $\begin{array}{l}\text { 5-(4-(Dimethylamino)benzylidene)-2-thioxo- } \\
\text { dihydropyrimidine- } 4,6(1 H, 5 H) \text {-dione }\end{array}$ & NA \\
\hline 21 & $\begin{array}{l}\text { 5-(2-Methylbenzylidene)-2-thioxodihydropy- } \\
\text { rimidine-4,6 }(1 H, 5 H) \text {-dione }\end{array}$ & $438.3 \pm 3.3$ \\
\hline 22 & $\begin{array}{l}\text { 5-(4-Ethoxybenzylidene)-2-thioxodihydropy- } \\
\text { rimidine-4,6 }(1 H, 5 H) \text {-dione }\end{array}$ & $230.7 \pm 2.6$ \\
\hline 23 & $\begin{array}{l}\text { 5-(2,4-Dihydroxybenzylidene)-2-thioxodihy- } \\
\text { dropyrimidine-4,6 }(1 H, 5 H) \text {-dione }\end{array}$ & $231.9 \pm 6.9$ \\
\hline
\end{tabular}




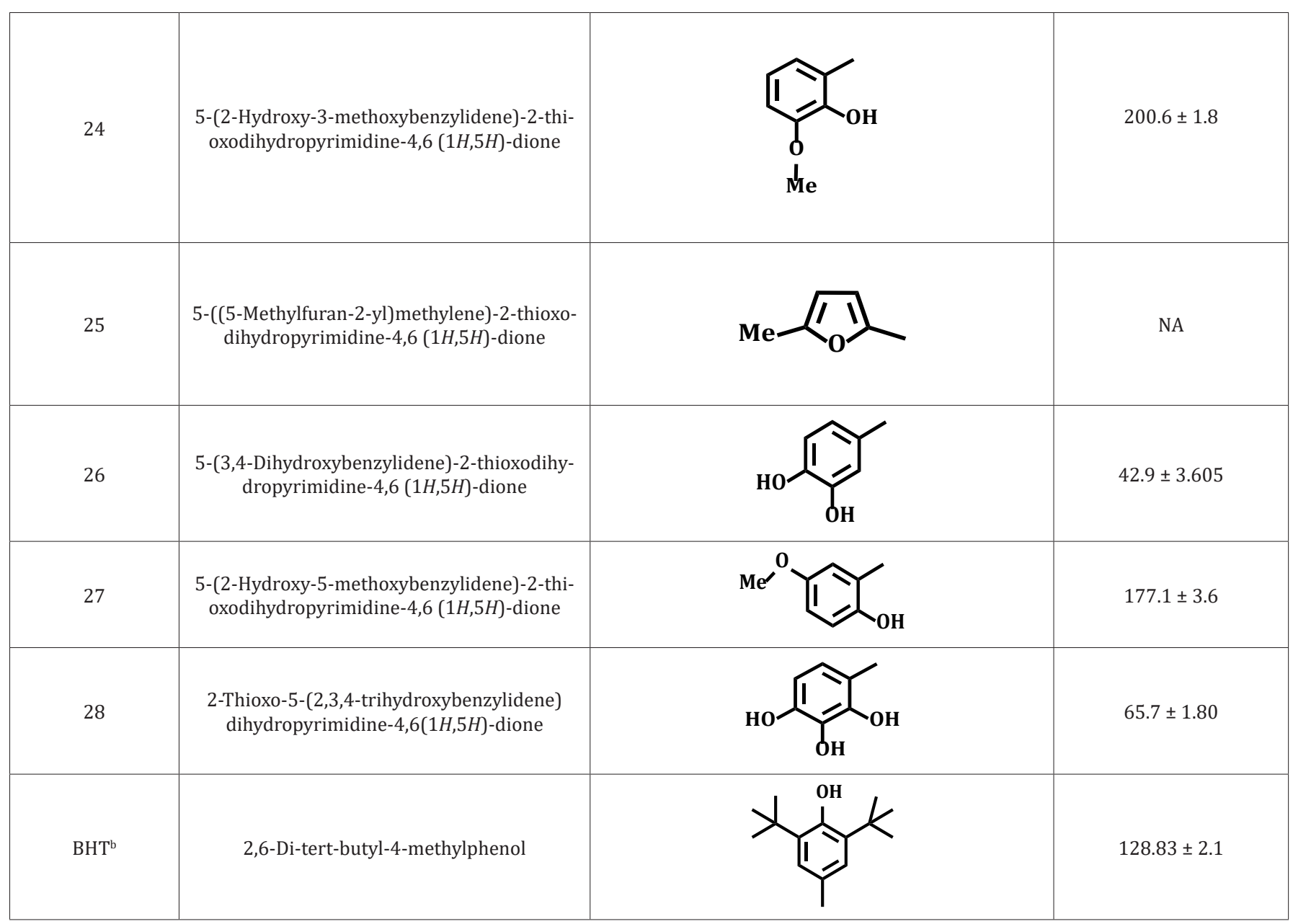

aSEM is the standard error of the mean, $\mathrm{BHT}^{\mathrm{b}}$ : Butylated hydroxytoulene

Table 2: \% Free radical scavenging activities of selected pyrimidine derivative.

\begin{tabular}{|c|c|c|c|}
\hline Compounds & \% Radical Scavenging Activity & Compounds & \% Radical Scavenging Activity \\
\hline 1 & 91.58 & 15 & 2.61 \\
\hline 2 & 89.25 & 16 & 1.52 \\
\hline 3 & 89.85 & 17 & 75.84 \\
\hline 4 & 13.45 & 18 & 81.95 \\
\hline 5 & 90.43 & 19 & 19.29 \\
\hline 6 & 78.00 & 20 & 53.44 \\
\hline 7 & 62.01 & 21 & 70.78 \\
\hline 8 & 74.35 & 22 & 81.96 \\
\hline 9 & 73.81 & 23 & 81.72 \\
\hline 10 & 75.00 & 24 & 15.54 \\
\hline 11 & 79.85 & 25 & 84.07 \\
\hline 12 & 90.76 & 26 & 81.36 \\
\hline 14 & 89.95 & 27 & 74.69 \\
\hline
\end{tabular}

\% RSA: \% Radical Scavenging Activity, Butylated hydroxytoulene (BHT) \% RSA: 85.87. 
Compound $\mathbf{1}$ is the second most potent derivative among the series, containing 4-hydroxy-3,5-dimethoxy groups with $\mathrm{IC}_{50}$ of value $55.6 \pm 2.1 \mu \mathrm{M}$, with corresponding $91.58 \%$ radical scavenging activity (Tables $1 \& 2$ ). With $74.69 \%$ radical scavenging activity derivative $\mathbf{2 8}$ with three hydroxyl groups at 2,3, and 4-positions, was found to be the third most effective derivative of the series (Tables $1 \& 3$ ). The lesser activity shown by analogue 28 as compared to compound $\mathbf{2 6}$ might be due to the extra hydroxyl group which creates some steric hindrance (Tables 1 \& 2). In this study, we observed that all other hydroxyl group containing derivatives, such as $3,11,13,15,19,23$ and 27, also showed antioxidant activity. The lesser activity shown by analogue $\mathbf{2 8}$ as compared to compound $\mathbf{2 6}$ might be due to the extra hydroxyl group which creates some steric hindrance (Tables $1 \& 2$ ).

In this study, we observed that all other hydroxyl group containing derivatives, such as $3,11,13,15,19,23$ and 27, also showed antioxidant activity. The difference in their activity seems to be either due to the number, position, and presence of other substituents along with the hydroxyl group (Table 1). Compound $\mathbf{8}$, and $\mathbf{1 2}$ have almost identical free radical scavenging activity with $74.3 \%$, and $90.76 \%$ (Table 2) (Figure 4). The moderate activity of compound 8 may be due to the lone pair of electrons on the pyridine nitrogen while in derivative $\mathbf{1 2}$, due to the presence of two methoxy groups (Table 1). Compound 7, and with (6-bromo-4-chloro-2-oxo-2H-chromen-3-yl) and (6-bromo4-chloro-2-oxo-2 -chromen-3-yl) substitutions were found to be the least active of the series (Tables $1 \& 2$ ).

The anthranyl analogue 14, di tert-butyl compound 16, derivative $\mathbf{1 7}$ having aminobenzylidene, derivative $\mathbf{2 0}$ with dimethylamino group, methylfuryl molecule 25, and thiophenyl derivative 4 did not show any antioxidant activity 4-Bromo-2,5dimethoxy compound $\mathbf{1 0}$ and 2-bromo-4,5-dimethoxy analogue 2 have the same substituents but their positions are different, providing little difference in their activities (Table-1) (Figure 5). By changing the substituent from $p$-thiomethyl, as in analogue $\mathbf{6}$, to an amino groups such as $\mathrm{N}, \mathrm{N}$-dimethyl amino derivative 19 and methyl-2-pyridinyl molecule $\mathbf{9}$, it was observed the amino analogues showed greater radical scavenging activity than the one with $p$-thiomethyl and $N, N$-dimethyl amino functionalities. This might be due to the better ability of the former to provide free electrons (Tables-1, and 2).

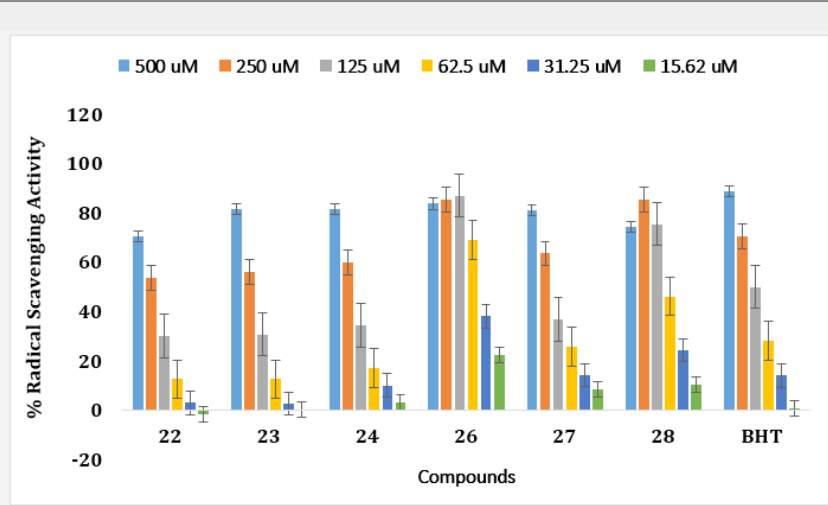

Figure 5: Concentrations dependent changes in free radical scavenging activities of pyrimidine derivatives [22-28].

\section{Cell Cytotoxic Activity}

Cytotoxicity of compounds $1,2,3,5,6,7,8,9,10,12,13,15$, 19, 20, 21, 24, 25, 26 and 28 was carried out by using mouse fibroblast 3T3 cell line. Derivatives 1, 3, 5, 6, 8, 9, 12, 13, 15, $19,21,24,25,26$ and 28 exhibited non-cytotoxicity in mouse

Table 3: Cytotoxicity studies of selected pyrimidine derivatives. fibroblast 3T3 cell line (Table 3). Derivatives $\mathbf{7}$ and $\mathbf{2 0}$ were found to have weak cytotoxic effect with $\mathrm{IC}_{50}$ values of $27.038 \pm 0.26$, and $22.4 \pm 0.76, \mu \mathrm{M}$, respectively. However, compound 2 was found to be moderately cytotoxic with $\mathrm{IC}_{50}$ value of $19.482 \pm 0.406 \mu \mathrm{M}$, and only compound $\mathbf{1 0}$ was found to be cytotoxic with $\mathrm{IC}_{50}$ value of $7.038 \pm 0.26 \mu \mathrm{M}$.

\begin{tabular}{|c|c|c|c|}
\hline Compounds & Cell Cytotoxicity (3T3 cell line) $\mathrm{IC}_{50}(\mu \mathrm{M}) \pm$ SEM & Compounds & $\begin{array}{c}\text { Cell Cytotoxicity (3T3 cell line) } \mathrm{IC}_{50}(\mu \mathrm{M}) \pm \\
\text { SEM }\end{array}$ \\
\hline 1 & $>30$ & 12 & $>30$ \\
\hline 2 & $19.482 \pm 0.40$ & 13 & $>30$ \\
\hline 3 & $>30$ & 15 & $>30$ \\
\hline 5 & $>30$ & 19 & $>30$ \\
\hline 6 & $>30$ & 20 & $22.4 \pm 0.768$ \\
\hline
\end{tabular}




\section{Cancer Therapy \& Oncology International Journal}

\begin{tabular}{|c|c|c|c|}
\hline 7 & $27.038 \pm 0.26$ & $\mathbf{2 1}$ & $>30$ \\
\hline 8 & $>30$ & $\mathbf{2 4}$ & $>30$ \\
\hline 9 & $>30$ & $\mathbf{2 5}$ & $>30$ \\
\hline 10 & $7.038 \pm 0.26$ & $\mathbf{2 6}$ & $>30$ \\
\hline Cycloheximide & $0.26 \pm 0.1$ & $\mathbf{2 8}$ & $>30$ \\
\hline
\end{tabular}

SEM: Standard Error Mean, Cycloheximide Standard Drug

\section{Conclusion}

The present study identifies new series of pyrimidines as potential radical scavengers. All analogues were found to display diverse free radical scavenging potential when compared with the standard butylated hydroxytoluene. Compounds 1, 3, 11, 13, $\mathbf{1 7}, \mathbf{2 5}$, and 27, with $\mathrm{IC}_{50}$ values of $55.6 \pm 2.1,122.4 \pm 1.9,107.65$ $\pm 1.3,108.4 \pm 2.8,113.4 \pm 1.3,42.9 \pm 0.31$, and $65.7 \pm 1.80 \mu \mathrm{M}$, respectively, showed good free radical scavenging potential better than the standard butylated hydroxytoluene having $\mathrm{IC}_{50}$ value of $128.83 \pm 2.1 \mu \mathrm{M}$. Cytotoxic evaluation of selected derivatives further support our study. Compound 1, 13, and 25 were identified as non-cytotoxic against 3T3 cells; therefore, these can serve as lead compounds for further development as potential drug candidates to scavenge reactive oxygen species.

\section{Acknowledgment}

The author is thankful to the International Center for Chemical and Biological Sciences to provide Prof. Dr. Salim-uzZaman Siddiqui (late) Scholarship and PCMD grant, Molecular Bank of the Dr. Panjwani Center for Molecular Medicine and Drug Research, International Center for Chemical and Biological Sciences, University of Karachi, Pakistan to provide substituted pyrimidines.

\section{ORCID ID}

https://orcid.org/0000-0003-4092-6900

\section{arXiv}

\section{https://arxiv.org/abs/2003.04538}

\section{References}

1. Neha K, Haider M R, Pathak A, Yar M S (2019) Medicinal prospects of antioxidants: A review. Eur J Med Chem 178: 687-704.

2. Ain, Qurat-ul (2019) Study of the Effect of Antioxidant on Oxidative Stress in Molecular and Cellular Models. (Doctoral dissertation, University of Karachi, Karachi) 1-227.

3. Suleman M, Khan A, Baqi A, Kakar MS, Ayub M, et al. (2019) Antioxidants, its role in preventing free radicals and infectious diseases in human body. Pure and Applied Biology 8: 380-388.

4. Young A, Lowe G (2018) Carotenoids-antioxidant properties. Antioxiants, 7: 28.

5. Pisoschi AM, Pop A, The role of antioxidants in the chemistry of oxidative stress: A review. Eur J Med Chem 97: 55-74.
6. Qurat-ul-Ain, Choudhary MI, Kochanek KS (2017) Modulation of melanoma cell proliferation and spreading by novel small molecular weight antioxidants. Free Radical Biology and Medicine 108: S28.

7. Sankarganesh M, Revathi N, Raja JD, Sakthikumar K, Kumar GG V, et al. (2019) Computational, antimicrobial, DNA binding and anticancer activities of pyrimidine incorporated ligand and its copper (II) and zinc (II) complexes (II) complexes. Journal of Serbian Chemical Society 84: 277-291.

8. Haleel AK, Rafi UM, Mahendiran D, Mitu L, Veena V (2019) DNA profiling and in vitro cytotoxicity studies of tetrazolo [1,5-a] pyrimidine-based copper (II) complexes. Biometals, 32(4): 1-16.

9. P Shringare SN, Chavan HV, Bhale S, Dongare SB, Mule YB, et al. (2018) Synthesis and pharmacological evaluation of pyrazoline and pyrimidine analogs of combretastatin-A4 as anticancer, anti-inflammatory and antioxidant agents. Croatica Chemical Acta 91(3): 1-10.

10. Wang Z, Kang D, Chen M, Wu G, Feng D, et al. (2018) Design, synthesis, and antiviral evaluation of novel hydrazone- substituted thiophene [3, 2-d] pyrimidine derivatives as potent human immunodeficiency virus-1 inhibitors. Chem Biol Drug Des 92(26): 2009-2021.

11. Kumar S, Deep A, Narasimhan B (2019) A Review on Synthesis, Anticancer and Antiviral Potentials of Pyrimidine Derivatives. Current Bioactive Compounds 15(3): 289-303.

12. Selvam TP, James CR, Dniandev PV, Valzita SK, A mini review of pyrimidine and fused pyrimidine marketed drugs. Journal of Research in Pharmacy Practice 2(4): 01-09.

13. Tokunaga S, Takashima T, Kashiwagi S, Noda S, Kawajiri H, et al. (2019) Neoadjuvant Chemotherapy with Nab-paclitaxel Plus Trastuzumab Followed by 5-Fluorouracil/Epirubicin/Cyclophospha mide for HER2-positive Operable Breast Cancer: A Multicenter Phase II Trial. Anticancer Res 39(4): 2053-2059.

14. Ghorab MM, Alsaid MS (2016) Anticancer activity of some novel thieno [2, 3-d] pyrimidine derivatives. Biomedical Research 27(1): 110-115.

15. Wilhelm M, Mueller L, Miller MC, Link K, Holdenrieder S, et al. (2016) Prospective, multicenter study of 5-fluorouracil therapeutic drug monitoring in metastatic colorectal cancer treated in routine clinical practice. Clin Colorectal Cancer 15(4): 381-388.

16. Smaill JB, Gonzales A J, Spicer JA, Lee H, Reed JE, et al. (2016) Tyrosine kinase inhibitors. 20. Optimization of substituted quinazoline and pyrido [3, 4-d] pyrimidine derivatives as orally active, irreversible inhibitors of the epidermal growth factor receptor family. J Med Chem 59(17): 8103-8124

17. Ghoneim AA, El-Farargy AF, Elkanzi NA (2019) Synthesis of some novel phenylfuro [3, 2-d] pyrimidine glycosides derivatives with expected antimicrobial activity. J Iran Chem Soc 17(2): 319-325.

18. Kumar MS, Aanandhi MV (2020) Design, molecular docking, synthesis, and biological evaluation of pyrido pyrimidine and pyrazolo pyrimidines for cytotoxic activity. Drug Invent Today 14(1).

19. Abdel-Megeed RM, Kadry MO, Fayed DB, Abdel-Hamid AH Z (2019) Antimicrobial activity and acetylcholinestrase inhibition of novel syn- 


\section{Cancer Therapy \& Oncology International Journal}

thesized pyrimidine derivatives versus Candida albicans trafficking to brain and kidney. Toxicol Rep 6: 262-266.

20. Sahoo BM, BVV R K (2020) Molecular Docking and Microwave Assisted Green Synthesis of Pyrimidine Derivatives as Potential Anti-tubercular agent SSRN 3535296

21. Istanbullu H, Bayraktar G, Akbaba H, Cavus I, Coban G, et al. (2020) Design, synthesis, and in vitro biological evaluation of novel thiazolopyrimidine derivatives as antileishmanial compounds. Arch Pharm e1900325.

22. Wang R, Yu S, Zhao X, Chen Y, Yang B, et al. (2020) Design, synthesis, biological evaluation and molecular docking study of novel thieno [3, 2-d] pyrimidine derivatives as potent FAK inhibitors. Eur J Med Chem 188: 112024

23. Khan KM, Rahim F, Khan A, Shabeer M, Hussain S, et al. (2014) Synthesis and structure-activity relationship of thiobarbituric acid derivatives as potent inhibitors of urease. Bioorganic and Medicinal Chemistry 22(15): 4119-4123.

24. Barakat A, Islam MS, Al-Majid AM, Ghabbour HA, Yousuf S, et al. (2016) Synthesis of pyrimidine-2,4,6-trione derivatives: Anti-oxidant, anti-cancer, $\alpha$-glucosidase, $\beta$-glucuronidase inhibition and their molecular docking studies. Bioorganic Chemistry 68: 72-79.
25. Reddy EK, Remya C, Sajith AM, Dileep KV, Sadasivan C, et al. (2016) Functionalized dihydroazo pyrimidine derivatives from Morita-Baylis-Hillman acetates: synthesis and studies against acetylcholinesterase as its inhibitors. RSC Advances 6: 77431-77439.

26. Sahu M, Siddiqui N (2016) A review on biological importance of pyrimidines in the new era. Journal of Pharmacy and Pharmaceutical Sciences 8: 8-21.

27. Ke S, Shi L, Zhang Z, Yang Z (2017) Steroidal [17, 16-d] pyrimidines derived from dehydroepiandrosterone: A convenient synthesis, antiproliferation activity, structure-activity relationships, and role of heterocyclic moiety. Scientific Reports 7: 44439.

28. Madhu K (2013) Phytochemical screening and antioxidant activity of in vitro grown plants Clitoria ternatea L., using DPPH assay. Asian Journal of Pharmaceutical Clinical Research 6: 38-42.

29. Vemana HP, Barasa L, Surubhotla N, Kong J, Ha SS, et al. (2019) Benzimidazole scaffolds as potential anticancer agents: Synthesis and Biological evaluation. The FASEB Journal 33(1): 646.18.

\section{Your next submission with Juniper Publishers} will reach you the below assets

- Quality Editorial service

- Swift Peer Review

- Reprints availability

- E-prints Service

- Manuscript Podcast for convenient understanding

- Global attainment for your research

- Manuscript accessibility in different formats ( Pdf, E-pub, Full Text, Audio)

- Unceasing customer service

Track the below URL for one-step submission https://juniperpublishers.com/online-submission.php 